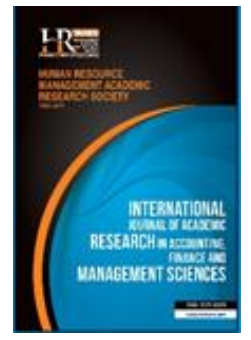

International Journal of Academic Research in Accounting, Finance and Management Sciences

Vol. 8, No.2, April 2018, pp. 250-258

E-ISSN: 2225-8329, P-ISSN: 2308-0337

(c) 2018 HRMARS

www.hrmars.com

To cite this article: Juhmani, O.I. (2018). The Effectiveness of Audit Committee on Curbing Earnings Management Practices - pre and post - BCGC 2011: Further Look, International Journal of Academic Research in Accounting Finance and Management Sciences 8 (2): 250-258.

\title{
The Effectiveness of Audit Committee on Curbing Earnings Management Practices - pre and post - BCGC 2011: Further Look
}

Omar Issa JUHMANI

Accounting Department, College of Business Administration, University of Bahrain, E-mail: ojuhmani@uob.edu.bh

Abstract

The aim of this study is to provide the second evidence on the effectiveness of Bahraini corporate governance code (BCGC) 2011 on curbing earnings management practices. It's my second study to measure the effectiveness of BCGC 2011. I used same study sample as in the first study, but in the current study the study period includes three study intervals; two years data (Pre- BCGC 2011) with one interval (i e. 2009, 2010) and four years data (Post- BCGC 2011) with two intervals (i e. 2012 and 2013; 2015 and 2016). The results of the regression model for the three study intervals show that earnings management does not significantly associated with any of the Audit Committee characteristics even pre- or post- BCGC 2011. However, in the two studies, the descriptive statistical test results show that, there is a clear evidence on the decrease of the level of earnings management practices after implementing the BCGC 2011. These results may provide new evidence that, Audit Committees by its own are not enough on curbing earnings management practices. Therefore, a future study is needed to examine the impact of BCGC 2011 on earnings management by using board characteristics in addition to Audit Committee characteristics in the regression model.

Key words Effectiveness, BCGC 2011, Audit Committee, earnings management, Bahrain

Revised: 09 Jul $2018 \quad$ Published by Human Resource Management Academic Research Society (www.hrmars.com)

Accepted: $22 \mathrm{Jul} 2018$ This article is published under the Creative Commons Attribution (CC BY 4.0) license. Anyone may Published Online: $\quad 31$ Jul 2018 reproduce, distribute, translate and create derivative works of this article (for both commercial and noncommercial purposes), subject to full attribution to the original publication and authors. The full terms of this license may be seen at: http://creativecommons.org/licences/by/4.0/legalcode

\section{Introduction}

Due to a series of major corporate failures, examples are WorldCom and Enron, corporate governance has received much attention all over the world since early 2000's when almost every country has been trying to develop, improve and implement strong Corporate Governance Codes (CGCs). Cohen et al., (2008) suggest that, the central objective of CGCs is to restore the reliability of financial statements by curbing earnings management and accounting fraud.

The credibility and transparency of financial statement of a company depends on the effectiveness of the monitoring mechanism of the company (Fama and Jensen, 1983), several empirical researchers have identified the role of the Audit Committee (AC) as being critical in ensuring credibility of the financial statement (e. g. Abbott et al., 2000). The effectiveness of ACs has been a subject of increasing interests due to increased concerns about the quality of corporate financial reporting process caused by accounting scandals. Therefore, the Sarbanes-Oxley Act (SOX) of 2002 in the U.S. mandates the role of the AC and strengthens its composition to oversee the financial reporting process. The Blue Ribbon Committee (1999), in its ten recommendations submitted on the AC, called for ACs to be more effective in overseeing the financial reporting process and improving the quality of financial reporting practices including earnings.

To improve the transparency, timeliness, quality of financial reporting and to restore the confidence to the investors, different laws, provisions, recommendations and codes were puts in place, for example, 
the SOX (2002), the recommendations of Blue Ribbon Committee (1999) and the provisions of SEC Code. In Bahrain the first CGC has been effective on $1^{\text {st }}$ January 2011. All Bahraini companies to which this Code applies should be in full compliance by the end of 2011. The BCGC 2011 is expected to enhance the power and responsibility of ACs, which play a crucial role in ensuring reliable financial reporting, internal controls, external auditing, and risk management, as a result, the of effectiveness ACs will enhance to mitigate corporate accounting and financial scandals. For example, the BCGC 2011 recommends most of the AC members should have the financial literacy qualifications. Financial experts with a high degree of accounting knowledge are expected to enhance the $A C^{\prime} s$ effectiveness in monitoring earnings management.

The BCGC 2011 is in line with the recommendations by Blue Ribbon Committee (1999), which emphasize the AC to be comprised of at least three directors who are independent and financially literate, and in line with the SOX (2002) which emphasize the importance of the independence of the AC for effective monitoring of financial reporting, and requires all AC members to be independent. Also, the BCGC 2011 is in line with the SEC Code, which emphasizes the AC to be fully independent and effective committee, and requires majority of the members to be independent directors or non-executive directors.

This study is conducted against the backdrop of increased regulation of Bahrain corporate governance, and it provides new evidence on the effectiveness of the AC characteristics on curbing earnings management practices. In this study I used the same methodology which I used in my first study (Juhmani, 2017), and like the first study I used only AC characteristics without using other corporate governance mechanisms such as board characteristics. However, in this study I used longer study periods pre- and post- BCGC 2011, not only two years as in the first study.

This study will be interesting for investors and auditors in Bahrain. It will provide them awareness about the use of earnings management by managers. Also, this study will be interesting for regulators in Bahrain, as mentioned by Zang (2012) it will make regulators be aware that when the scrutiny increased, it does not eliminate earnings management activities, but it may only change managers' strategy of using earnings management.

\section{Literature Review and Hypotheses}

\subsection{Literature review}

Managements have incentives to manipulate earnings to achieve pre-determined benchmarks or stockholders' expectations. Earnings management is widely supposed as a means of manipulating accounting earnings to benefit managers at the expense of shareholders. Discretionary accruals (as proxies for earnings management) have been using to manipulate accounts and mislead investors; AC believed will contribute on curbing earnings management practices. The effectiveness of ACs has been a subject of increasing interests; an independent and expert AC member can help mitigate earnings management and misreporting. However, few studies have investigated the effectiveness of CGCs on curbing earnings management practices by measuring the association between $A C$ characteristics and earnings management in the pre- and post CGCs periods. For example, Salleh and Haat (2014) examined the effectiveness of AC in constraining earnings management after the revised Malaysian Code on Corporate Governance (MCCG) 2007 among listed firms on Bursa Malaysia. After controlling for firm size, board size and leverage, they found that $A C$ expertise, $A C$ independence, $A C$ disclosure and frequency of meetings are variables that showed negative association with earnings management after the revised of MCCG.

The post-SOX literature establishes the notion that independent and expert ACs help in reducing earnings management and internal control deficiencies and improve financial reporting and audit quality. These findings supplement the significance and implications of SOX. Thus, researchers have extensively investigated the issues of earnings management, around the passage of the SOX to test the association between corporate governance and earnings management in the pre- and post-SOX periods, for example Farber (2005) by using pre-SOX data found that fraud firms have fewer AC meetings and less financial expertise in the AC, Cohen et al. (2008) found that the level of real earnings management declined prior to SOX and increased significantly after the passage of the SOX of U.S. listed companies. 


\subsection{Hypotheses}

\subsubsection{Audit Committee Size}

A large AC size may play a vital role in constraining the occurrence of earnings management. However, the literature provides mixed results on the association between AC size and earnings management. For example, Lin and Hwang (2010) and Fodio et al. (2013) found a negative significant association. Ghosh et al. (2010) found that AC size is influencing discretionary accruals at the pre-SOX period and not at the post-SOX period. While, other found no significant relationship between ACs size and earnings management, for example, Xie et al. (2003), Abbott et al. (2004) and Davidson et al. (2005).

Despite the inconsistent findings in the literature reported above, this study proposes that, If the BCGC 2011 is effective in ensuring that Bahraini listed firms' management maintains a strong system for monitoring financial-reporting processes through the requirements of $A C$ size, the association between earnings management and AC size is expected to be negative post- BCGC 2011. However, to present evidence on whether the BCGC 2011decreases the level of earnings management, this study investigated this issue by comparing the regression results in the pre- and post BCGC periods. Therefore, in this study the following hypotheses will be tested.

$H_{1}$ : The audit committee size is negatively associated with earnings management in the pre- BCGC 2011.

$\mathrm{H}_{2}$ : The audit committee size is negatively associated with earnings management in the post- BCGC 2011.

\subsubsection{AC Meetings}

The literature provides mixed results on the association between $A C$ meetings and earnings management. For example, Xie et al. (2003) by using pre-SOX samples found a negative association between frequency of AC meetings and earnings management. Salleh and Haat (2014) found that frequency of meetings is negatively associated with earnings management after the revised Malaysian Code on Corporate Governance. However, other researchers found no association between ACs meetings and the level of earnings management, for example, Bédard et al., (2004) and Lin et al., (2006).

Despite the inconsistent findings in the literature reported above, this study proposes that, If the BCGC 2011 is effective in ensuring that Bahraini listed firms' management maintains a strong system for monitoring financial-reporting processes through the requirements of the frequency of $A C$ meetings, the association between earnings management and AC meetings is expected to be negative post- BCGC. Therefore, and to compare the results of the pre- BCGC and post- BCGC periods, the following hypotheses will be tested.

$H_{3}$ : The frequency of audit committee meetings is negatively associated with earnings management in the pre- BCGC 2011.

$\mathrm{H}_{4}$ : The frequency of audit committee meetings is negatively associated with earnings management in the post- BCGC 2011.

\subsubsection{AC expertise}

The literature provides mixed results on the association between $A C$ expertise and earnings management. For example, Dhaliwal et al. (2006) investigated the association between three types of AC financial expertise (accounting, finance and supervisory expertise) and accruals quality, they found significant positive relation between accounting expertise and accruals quality. However, Xie et al. (2003) by using pre-SOX samples found that $A C$ members with financial expertise are negatively associated with earnings management, and Salleh and Haat (2014) found that AC expertise is negatively associated with earnings management after the revised Malaysian Code on Corporate Governance.

Despite the inconsistent findings in the literature reported above, this study proposes that, If the BCGC 2011 is effective in ensuring that Bahraini listed firms' management maintains a strong system for monitoring financial-reporting processes through the requirements of $A C$ members with high degree of expertise, the association between earnings management and AC expertise is expected to be negative post- 
BCGC. Therefore, and to compare the results of the pre- BCGC and post- BCGC periods, the following hypotheses will be tested.

$H_{5}:$ The audit committee expertise is negatively associated with earnings management in the preBCGC 2011.

$H_{6}:$ The audit committee expertise is negatively associated with earnings management in the postBCGC 2011.

\section{Methodology of research}

To present a further evidence on the effectiveness of the AC characteristics on curbing earnings management practices in Bahrain, in this study I used the same methodology which I used in my first study (Juhmani, 2017), and like the first study I used only AC characteristics without using other corporate governance mechanisms such as board characteristics. However, in this study I used longer study periods pre- and post- BCGC 2011, not only two years as in the first study.

\subsection{Definitions and Measurement of the Dependent Variable}

The dependent variable is earnings management, as in my first study I used discretionary accruals as proxies for earnings management, and to estimate discretionary accruals I used the modified- Jones (1991) model.

\subsection{Definitions and Measurement of the Independent and Control Variables:}

The three independent variables (i e. AC characteristics) and three control variables are defined and measured as shown in Table 1.

\subsection{Study Sample and Regression Model}

This study investigated the issue of the effectiveness of the AC characteristics on curbing earnings management practices in Bahrain by comparing the regression results in the pre- and post- BCGC 2011. The initial study sample includes all Bahraini companies listed on the Bahrain Bourse for the years 2009, 2010, 2012, 2013, 2015 and 2016, two years data (Pre- BCGC 2011) with one interval and four years data (PostBCGC 2011) with two intervals. After excluding suspended companies and excluding companies with incomplete financial data, 70, 64 and 68 observations for the three intervals respectively are included in the regression analyses. To examine the associations between AC characteristics and earnings management pre- and post- BCGC 2011, the following regression model is developed and executed separately for the three study intervals.

$$
\begin{aligned}
& \mathrm{EM}=\beta_{0}+\beta_{1} \text { ACSIZE }+\beta_{2} \text { ACMET }+\beta_{3} \text { ACEXP }+\beta_{4} \text { COSIZE }+\beta_{5} \text { LEVG }+\beta_{6} \text { AUDFSZ }+\epsilon \\
& \text { Where: } \\
& \text { EM = Earnings management; } \\
& \text { ACSIZE = Audit committee size; } \\
& \text { ACMET = Audit committee meetings; } \\
& \text { ACEXP = Audit committee experts; } \\
& \text { COSIZE }=\text { Company size; } \\
& \text { LEVG }=\text { Leverage; } \\
& \text { AUDFSZ }=\text { Audit firm size; } \\
& \epsilon \quad=\text { error term. }
\end{aligned}
$$

Table 1. Variables Definitions and Measurements

Variables

Dependent variable EM Independent variables

ACSIZE

ACMET
Definitions and Measurements

Earnings management, measured by discretionary accruals as a proxy.

Audit committee size, measured by number of members on the audit committee;

Audit committee meetings, measured by number of audit committee meetings held during the fiscal year; 


\section{ACEXP}

\section{Control variables}

COSIZE

LEVG

AUDFSZ
Audit committee experts, measured as a percentage of audit committee members having expertise in accounting or financial management.

Company size, measured by the companies' natural log of total assets; Leverage, measured as the ratio of the companies' total liabilities to the companies' total assets.

Audit firm size, a dummy variable that equals 1 if the company is audited by Big-4 auditor and 0 otherwise;

\section{Results and Discussions}

The descriptive statistical test results of all variables for the sample of companies for the three study intervals are presented in Tables 2, 3 and 4. The results show that, the average of earnings management (EM) for 2009 and 2010 (Pre- BCGC period) is .5508 and for 2015 and 2016 (Post- BCGC period) is .1380, this result suggests that the overall level of earnings management decline post- BCGC period. The average value of AC size (ACSIZE) in Pre- BCGC period was 3.514 and increased to 3.74 members in the Post- BCGC period, and the maximum number of members in $A C$ increased from 5 members to 7 members. The average number of AC meetings (ACMET) held during 2009 and 2010 (Pre- BCGC period) is 3.78 and that held during 2015 and 2016 (Post- BCGC period) is 4.53, this result indicates that there is increase in the number of AC meetings after implementing BCGC 2011. Also, the average percentage of AC members having experience in accounting or financial management (ACEXP) for 2009 and 2010 is .785 and for 2015 and 2016 is .99, which indicate a clear increase in the level of AC experts after implementing BCGC 2011.

Table 2. Descriptive Statistics for Years 2009 and 2010 (Pre- BCGC 2011)

\begin{tabular}{ccccc}
\hline & Minimum & Maximum & Mean & Std. Deviation \\
\hline EM & -8.9388 & 6.4305 & .55085 & 1.6823 \\
ACSIZE & 3 & 5 & 3.51428 & .6311 \\
ACMET & 1 & 6 & 3.78571 & 1.0056 \\
ACEXP & 0 & 1 & .785714 & .41328 \\
COSIZE & .2151 & 8.9684 & 6.30033 & 1.5152 \\
LEVG & .0035 & 9.1736 & 2.18726 & 2.8214 \\
AUDFSZ & 0 & 1 & .828571 & .37960 \\
\hline
\end{tabular}

Note: The variables are defined in Table 1.

Table 3. Descriptive Statistics for Years 2012 and 2013 (Post- BCGC 2011)

\begin{tabular}{ccccc}
\hline & Minimum & Maximum & Mean & Std. Deviation \\
\hline EM & .00450 & 5.07913 & .897701 & 1.18502 \\
ACSIZE & 2 & 7 & 3.75 & 1.054 \\
ACMET & 2 & 8 & 4.52 & 1.098 \\
ACEXP & .25 & 1.00 & .7499 & .22962 \\
COSIZE & 16.5504 & 23.233 & 19.3292 & 2.01333 \\
LEVG & .00199 & 1.70555 & .440298 & .339483 \\
AUDFSZ & 0 & 1 & .75 & .436 \\
\hline
\end{tabular}

Note: The variables are defined in Table 1.

Table 4. Descriptive Statistics for Years 2015 and 2016 (Post- BCGC 2011)

\begin{tabular}{ccccc}
\hline & Minimum & Maximum & Mean & Std. Deviation \\
\hline EM & .00000 & 1.43397 & .138066 & .251584 \\
ACSIZE & 2 & 7 & 3.74 & 1.031 \\
ACMET & 2 & 9 & 4.53 & 1.366 \\
ACEXP & 0 & 1 & .99 & .121 \\
COSIZE & 6.8378 & 10.1074 & 8.48506 & .897755 \\
LEVG & .00081 & 12.91009 & 2.44274 & 2.91836 \\
AUDFSZ & 0 & 1 & .87 & .341 \\
\hline
\end{tabular}

Note: The variables are defined in Table 1. 
Table 5. Pearson Correlations for Years 2009 and 2010 (Pre- BCGC 2011)

\begin{tabular}{|cccccccc}
\hline & EM & ACSIZE & ACMET & ACEXP & COSIZE & LEVG & AUDFSZ \\
\hline EM & 1 & & & & & & \\
ACSIZE & .003 & 1 & & & & & \\
& .980 & & & & & & \\
ACMET & $.273^{*}$ & .130 & 1 & & & & \\
& .022 & .282 & & & & \\
ACEXP & -.183 & .206 & -.217 & 1 & & & \\
& .130 & .087 & .072 & & & \\
COSIZE & .134 & -.142 & .087 & -.025 & 1 & & \\
& .269 & .242 & .472 & .838 & & \\
LEVG & $-.269^{*}$ & .055 & -.138 & -.108 & $-.362^{* *}$ & 1 & \\
& .024 & .650 & .253 & .371 & .002 & & \\
AUDFSZ & -.038 & .071 & .206 & -.053 & .182 & .229 & \\
& .758 & .560 & .087 & .664 & .131 & .057 & \\
\hline
\end{tabular}

*. Correlation is significant at the 0.05 level (2-tailed).

**. Correlation is significant at the 0.01 level (2-tailed).

Table 6. Pearson Correlations for Years 2012 and 2013 (Post- BCGC 2011)

\begin{tabular}{cccccccc}
\hline & EM & ACSIZE & ACMET & ACEXP & COSIZE & LEVG & AUDFSZ \\
\hline EM & 1 & & & & & & \\
ACSIZE & -.014 & 1 & & & & & \\
& .915 & & & & & \\
ACMET & .220 & .017 & 1 & & & \\
& .080 & .893 & & & & \\
ACEXP & -.215 & -.194 & -.156 & 1 & & \\
& .089 & .124 & .218 & & & \\
COSIZE & $.263^{*}$ & .222 & .059 & -.151 & 1 & & \\
& .036 & .077 & .641 & .234 & & \\
LEVG & .165 & $-.259^{*}$ & .155 & .051 & $.410^{* *}$ & 1 & \\
& .194 & .039 & .222 & .687 & .001 & & \\
AUDFSZ & .186 & $.414^{* *}$ & .041 & -.066 & -.012 & -.128 & 1 \\
& .140 & .001 & .745 & .602 & .927 & .314 & \\
\hline
\end{tabular}

*. Correlation is significant at the 0.05 level (2-tailed).

**. Correlation is significant at the 0.01 level (2-tailed).

Table 7. Pearson Correlations for Years 2015 and 2016 (Post- BCGC 2011)

\begin{tabular}{cccccccc}
\hline & EM & ACSIZE & ACMET & ACEXP & COSIZE & LEVG & AUDFSZ \\
\hline EM & 1 & & & & & & \\
ACSIZE & -.107 & 1 & & & & & \\
& .384 & & & & & & \\
ACMET & -.128 & $.239^{*}$ & 1 & & & \\
& .297 & .050 & & & & \\
ACEXP & -.128 & -.151 & .138 & 1 & & \\
& .300 & .219 & .262 & & & \\
COSIZE & -.006 & -.003 & $.245^{*}$ & .125 & 1 & & \\
& .960 & .979 & .044 & .311 & & \\
LEVG & -.201 & .099 & .061 & .100 & $.717^{* *}$ & 1 & \\
& .100 & .422 & .621 & .415 & .000 & & \\
AUDFSZ & -.034 & -.186 & .153 & $.313^{* *}$ & $.509^{* *}$ & $.261^{*}$ & \\
& .780 & .129 & .214 & .009 & .000 & .032 & \\
\hline
\end{tabular}

*. Correlation is significant at the 0.05 level (2-tailed).

**. Correlation is significant at the 0.01 level (2-tailed). 
The Pearson correlation coefficients between dependent and independent variables for the three study period intervals are presented in Tables 5, 6 and 7. The results show that there is a moderately high correlation between some variables. However, it has been suggested that correlation coefficients should not be considered harmful until they exceed 0.80 . The coefficients in the correlation matrix in Table 5 reveal that the highest correlation is (.362) between company size and leverage, and in Table 6 the highest correlation is (.414) between AC size and audit firm size, and in Table 7 the highest correlation is (.717) between company size and leverage, which support the lack of multicollinearity in the regression model.

To measure the effectiveness of the AC characteristics ( $i$ e. AC size, frequency of AC meetings and AC expertise) on curbing earnings management practices, this study investigated this issue by comparing the regression results in the pre- and post BCGC 2011 to present evidence on whether the BCGC 2011 decreases the level of earnings management. If there is a significant change of magnitude in the association between earnings management and AC characteristics in the post- BCGC period implies that, the effectiveness of the BCGC in monitoring earnings management practices is improved. By examining the change of magnitude in these associations, it can be identified any shift in corporate governance characteristics in monitoring earnings management between the pre- and post- BCGC 2011.

Table 8 presents the main results of the regression that examine the impact of AC effectiveness on curbing earnings management practices in Bahrain. The regression model is run separately for the three study period intervals 2009 and 2010; 2012 and 2013; 2015 and 2016, pre- and post BCGC 2011. The results of the regression model show that, earnings management significantly associated with some of the control variables (i e. company size and audit firm size) after implementing BCGC 2011.

Table 8. The Results of the Regression Model

\begin{tabular}{|c|c|c|c|}
\hline \multicolumn{4}{|c|}{ Dependent Variable } \\
\hline \multicolumn{4}{|c|}{ Earnings Management (EM) } \\
\hline Independent Variables & $\begin{array}{l}\text { Model (2009 and 2010) } \\
\text { (Pre- BCGC 2011) }\end{array}$ & $\begin{array}{l}\text { Model (2012 and 2013) } \\
\text { ( Post- BCGC 2011) }\end{array}$ & $\begin{array}{l}\text { Model (2015 and 2016) } \\
\text { (Post- BCGC 2011) }\end{array}$ \\
\hline Constant & $(-.182)$ & $(-1.147)$ & $(-.601)$ \\
\hline \multicolumn{4}{|l|}{ Audit Committee variables } \\
\hline ACSIZE & $\begin{array}{l}.034 \\
(.276)\end{array}$ & $\begin{array}{l}-.216 \\
(-1.478)\end{array}$ & $\begin{array}{l}-.052 \\
(-.398)\end{array}$ \\
\hline ACMET & $\begin{array}{l}.204 \\
(1.616)\end{array}$ & $\begin{array}{l}.168 \\
(1.380)\end{array}$ & $\begin{array}{l}-.163 \\
(-1.237)\end{array}$ \\
\hline ACEXP & $\begin{array}{l}-.172 \\
(-1.391)\end{array}$ & $\begin{array}{l}-.172 \\
(-1.396)\end{array}$ & $\begin{array}{l}-.094 \\
(-.728)\end{array}$ \\
\hline \multicolumn{4}{|l|}{ Control variables } \\
\hline COSIZE & $\begin{array}{l}.039 \\
(.295)\end{array}$ & $\begin{array}{l}.273 \\
(1.917) *\end{array}$ & $\begin{array}{l}.407 \\
(1.996) * *\end{array}$ \\
\hline LEVG & $\begin{array}{l}-.237 \\
(-1.752) *\end{array}$ & $\begin{array}{l}.013 \\
(.092)\end{array}$ & $\begin{array}{l}-.448 \\
(-2.484) * * *\end{array}$ \\
\hline AUDFSZ & $\begin{array}{l}-.044 \\
(-.342)\end{array}$ & $\begin{array}{l}.262 \\
(1.998) * *\end{array}$ & $\begin{array}{l}-.080 \\
(-.594)\end{array}$ \\
\hline R-Square & .158 & .200 & .129 \\
\hline Adjusted R-Square & .078 & .116 & .043 \\
\hline F-statistic & 1.968 & 2.373 & 1.501 \\
\hline Prob (F-statistic) & .084 & .3041 & .193 \\
\hline Obs & 70 & 64 & 68 \\
\hline
\end{tabular}

Note: The variables are defined in Table 1.

$t$-values in parentheses.

* Significant at the 0.10 level (2-tailed).

** Significant at the 0.05 level (2-tailed).

*** Significant at the 0.01 level (2-tailed). 
The effectiveness of the $A C$ on curbing earnings management is enhanced through large $A C$ size, frequency of $\mathrm{AC}$ meetings and the presence of financial or accounting experts on the committee. However, the results in Table 8 against my expectation that AC characteristics have a constraining effect on earnings management, the results show that neither variable has a significant association with the level of earnings management pre- or post BCGC 2011. Accordingly, all hypotheses of this study are rejected. These findings are consistent (for example) with Xie et al. (2003), Bédard et al. (2004) and Abbott et al. (2004) who found no significant relationship between ACs size and the level of earnings management, and consistent with Bédard et al., (2004) and Lin et al., (2006) who found no significance association between number of AC meetings and earnings management.

The results in Table 8 show that discretionary accruals as a proxy for earnings management does not significantly associated with any of the AC characteristics even before or after implementing BCGC 2011. The results of this study suggest that the effectiveness of the BCGC 2011 in monitoring and curbing earnings management practices doesn't improved even by using more year's data pre- and post- BCGC 2011 comparing with the study period of my first study. Therefore, the results of this study confirm the results of my first study (Juhmani, 2017) and the results of both studies may suggest that ACs lonely doesn't provide incremental monitoring on curbing earnings management in the post- BCGC period.

\section{Conclusions}

This study is a continuous research project with a further look to provide the second evidence on the effectiveness of BCGC 2011. It's my second study to measure the effectiveness of the BCGC 2011 on curbing earnings management practices by using $A C$ characteristics without using other corporate governance mechanisms such as board characteristics. To meet the objective of the current study, I used the same methodology which I used in my first study (Juhmani, 2017). The main difference between the two studies as follows; In the first study I used only two years data, one year before and one year after the BCGC 2011, but in the current study I used more year's data pre- and post- BCGC 2011, two years data (Pre- BCGC 2011) with one interval (i e. 2009, 2010) and four years data (Post- BCGC 2011) with two intervals (i e. 2012 and 2013; 2015 and 2016).

The AC characteristics examined in the current study are AC size, $A C$ meetings and $A C$ experts. To present evidence on whether the BCGC 2011 decreases the level of earnings management, this study investigated this issue by comparing the regression results in the pre- and post BCGC period. If the BCGC 2011 is effective in ensuring that Bahraini listed firms' management maintains a strong system for monitoring financial-reporting processes through the requirements of $A C s$, the association between earnings management and the AC characteristics is expected to be negative post- BCGC period.

The results of the descriptive statistical test in the current study are consistent with the results of the first study, both studies show that, the mean of earnings management variable derived from the modified Jones model Post- BCGC 2011 is less than the mean of earnings management Pre- BCGC 2011. These results suggest that there is a clear impact for implementing the BCGC 2011 on the decrease of the level of earnings management practices in Bahrain. However, the results of the regression model in the two studies show that discretionary accruals as a proxy for earnings management does not significantly associated with any of the AC characteristics. Therefore, the results of the two studies may provide evidence suggesting that, ACs and its characteristics by its own are not enough on curbing earnings management practices.

This study contributes to the existing literature in earnings management and corporate governance by testing the relation between $A C$ characteristics and earnings management practices two years data before implementing the first CGC in Bahrain and four years data after. The findings are useful for policymakers aiming to identify and devise key corporate governance mechanisms that are effective on curbing earnings management practices.

As shown above, the empirical results of this study and my first study reveal that AC characteristics by its own doesn't provide incremental monitoring on curbing earnings management practices. Therefore, to confirm this finding and to provide a new evidence on the important of the board and its characteristics on curbing earnings management practices, a future research is needed to examine the impact of BCGC 2011 on earnings management by using board characteristics in addition to AC characteristics in the regression model. 


\section{Acknowledgements}

The research is financed by the deanship of scientific research at University of Bahrain.

\section{References}

1. Abbott, L., Park, Y. and Parker, S. (2000), The effects of audit committee activity and independence on corporate fraud. Managerial Finance, 26 (11), 55-67.

2. Abbott, L., Parker, S. and Peters, G. (2004), Audit committee characteristics and restatements. Auditing: A Journal of Practice \& Theory, 23, 69-87.

3. Bédard, J., Chtourou, S. M. and Courteau, L. (2004), The effect of audit committee expertise, independence, and activity on aggressive earnings management. Auditing: A Journal of Practice \& Theory, 23(2), 13-35.

4. Blue Ribbon Committee (1999), Report and recommendations of the Blue Robin Committee on improving the effectiveness of corporate audit committees, New York: New York Stock Exchange and National Association of Securities Dealers.

5. Cohen, D. A., Dey, A., and Lys, T. Z. (2008), Real and accrual-based earnings management in the pre- and post-Sarbanes-Oxley periods. The Accounting Review, 83(3), 757- 787.

6. Davidson, R., Goodwin-Stewart, J. and Kent, P. (2005), Internal governance structures and earnings management. Accounting and Finance, 45 (2), 241-268.

7. Dhaliwal, D. S. and Naiker, V. and Navissi, F. (2006), Audit Committee Financial Expertise, Corporate Governance and Accruals Quality: An Empirical Analysis (May). SSRN: https://ssrn.com/ abstract=906690 or http://dx.doi.org/10.2139/ssrn.906690

8. Fama, E. F., and Jensen, M. C. (1983), Separation of ownership and control. Journal of Law and Economics, 26(2), 301-325.

9. Farber, D. B. (2005). Restoring trust after fraud: Does corporate governance matter? The Accounting Review, 80(2), 539-561.

10.Fodio, M. I., Ibikunle, J., and Oba, V. C. (2013), Corporate governance mechanisms and reported earnings quality in listed Nigerian insurance firms. International Journal of Finance and Accounting, 2(5), 279-286. doi:10.5923/j.ijfa.20130205.01

11.Ghosh, A., Marra, A., and Moon, D. (2010), Corporate boards, audit committees, and earnings management: pre- and post-SOX evidence. Journal of Business Finance \& Accounting, 37(9-10), 1145-1176. doi:10.1111/j.1468-5957.2010.02218.x

12.Jones, J. J. (1991), Earnings management during import relief investigations. Journal of Accounting Research, 29(2), 193-228.

13.Juhmani, O. I. (2017), "The Impact of Audit Committee Characteristics on Earnings Management in the Pre- and Post- Bahraini Corporate Governance Code 2011", Asian Journal of Economics, Business and Accounting, 4(3), 1-12.

14.Lin, J.W. and Hwang, M.I. (2010), Audit Quality, Corporate Governance, and Earnings Management: A Meta-Analysis. International Journal of Auditing, 14(1), 57-77.

15.Lin, J., Li, J. and Yang, J. (2006), The Effect of Audit Committee Performance on Earnings Quality. Managerial Auditing Journal, 21(9), 921-933.

16.Salleh N. M.and Haat M. H. (2014), Audit Committee and Earnings Management: Pre and Post MCCG, International Review of Management and Business Research, 3(1), 307-318.

17.Sarbanes-Oxley Act. (2002). 107th Congress of the United States of America. Washington DC.

18.Xie, B., Davidson, W.N. and DaDalt, P.J., (2003), Earnings management and corporate governance: the roles of the board and the audit committee. Journal of Corporate Finance, 9(3), 295-316.

19.Zang, A.Y. (2012), Evidence on the trade-off between real activities manipulation and accrualbased earnings management. The accounting Review, 87(2), 675-705. 